\title{
Digital Literacy Skills and Attitudes towards E-learning*
}

\begin{tabular}{ccc}
\hline Article Type & Received Date & Accepted Date \\
Research & 19.02 .2019 & 13.05 .2019 \\
\hline
\end{tabular}

\author{
Nazire Burçin Hamutoğlu** $\quad$ Merve Savaşçi**** \\ Gözde Sezen-Gültekin ${ }^{* * * * *}$
}

\begin{abstract}
This study aimed to investigate the attitudes towards e-learning and digital literacy skills of prospective teachers $(N=47)$ enrolled in the Department of Computer Education and Instructional Technology at a state university in Turkey. The study also investigated whether these variables vary in terms of gender and prior e-learning experience as well as the potential relationship between their attitudes and their digital literacy skills. Adopting a quasi-experimental pre-posttest design with an experimental group, this study sought to discover the effects of a fiveweek treatment on prospective teachers' digital literacy skills and attitudes toward e-learning. The data for the study came from two data collection tools namely, Attitudes towards E-learning Scale (Haznedar \& Baran, 2012) and Digital Literacy Scale (Ng, 2012). Findings indicated the effectiveness of the treatment on the participants' attitudes towards e-learning platforms. Furthermore, the findings of the regression tests demonstrated that tendency is one of the most significant predictors of digital literacy skills.
\end{abstract}

Keywords: Digital literacy, attitudes, Edmodo, e-learning, quasi-experimental.

\footnotetext{
* One part of this study was presented as an oral presentation at the $26^{\text {th }}$ International Conference on Educational SciencesICES, on 20-23 April 2017 in Antalya, Turkey.

** Corresponding Author: Dr, Kırşehir Ahi Evran University, Faculty of Education, Computer \& Instructional Technology Department, Kırşehir, Turkey. E-mail:bhamutoglu@ sakarya.edu.tr, https://orcid.org/ 0000-0003-0941-9070

${ }^{* * *}$ Ress. Assist, Sakarya University, Faculty of Education, Department of Foreign Languages Education, English Language Teaching Program, Sakarya, Turkey. E-mail:msavasci@ sakarya.edu.tr, https://orcid.org/ 0000-0002-4906-3630

${ }^{* * * *}$ Ress. Assist, Sakarya University, Faculty of Education, Department of Educational Sciences, Educational Administration and Supervision Program, Sakarya, Turkey. E-mail:gsezen@ sakarya.edu.tr, https://orcid.org/ 0000-0002-2179-4466
} 


\title{
Dijital Okuryazarlık Becerileri ve E-Öğrenmeye Yönelik Tutum*
}

\begin{tabular}{ccc}
\hline Makale Türü & Başvuru Tarihi & Kabul Tarihi \\
Araştırma & 19.02 .2019 & 13.05 .2019 \\
\hline
\end{tabular}

\author{
Nazire Burçin Hamutoğlu** $\quad$ Merve Savaşçi****
}

Gözde Sezen-Gültekin ****

\begin{abstract}
$\ddot{O}_{z}$
Mevcut çalışma, Türkiye'de bir devlet üniversitesinde Bilgisayar ve Öğretim Teknolojileri Eğitimi Bölümü'nde kayıtlı öğretmen adaylarının $(N=47)$ e-öğrenmeye yönelik tutumları ile dijital okuryazarlık becerileri arasındaki ilişkiyi ortaya koymayı amaçlamıştır. Çalışmada ayrıca bu değişkenlerin öğretmen adaylarının cinsiyet ve önceki e-öğrenme deneyimlerine göre farklılık gösterip göstermediğinin yanı sıra e-öğrenmeye yönelik tutum ve dijital okuryazarlık becerileri arasındaki muhtemel ilişski araştırılmıştır. Araştırmada öntest sontest tek deney gruplu yarı deneysel desen kullanılmış olup, araştırmada beş haftalık deneysel bir eğitimin katılımcıların dijital okuryazarlık becerileri ve e-öğrenmeye yönelik tutumları üzerindeki olası etkileri araştırılmıştır. Veriler E-öğrenmeye Yönelik Genel Tutum Ölçeği (Haznedar \& Baran, 2012) ve Dijital Okuryazarlık Ölçeği $(\mathrm{Ng}, 2012)$ aracılığı ile toplanmıştır. Sonuçlar, araştırmada yürütülen deneysel eğitimin katılımcıların e-öğrenme platformlarına yönelik tutumları üzerindeki etkinliğini göstermiştir. Buna ek olarak, regresyon testlerinin sonuçları, eğilimin dijital okuryazarlığın en önemli yordayıcılardan biri olduğunu göstermektedir.
\end{abstract}

Anahtar Sözcükler: Dijital okuryazarlık, tutum, Edmodo, e-öğrenme, yarı deneysel desen.

\footnotetext{
*Bu çalışmanın bir kısmı 20-23 Nisan 2017 tarihleri arasında Antalya'da gerçekleştirilen 26. Uluslararası Eğitim Bilimleri Kongresi'nde-UEBK-2017, sözlü bildiri olarak sunulmuştur.

** Sorumlu Yazar: Dr, Kırşehir Ahi Evran Universitesi, Eğitim Fakültesi, Bilgisayar ve Öğretim Teknolojileri Eğitimi Bölümü, Kırşehir, Türkiye. E-posta: bhamutoglu@ sakarya.edu.tr, https://orcid.org/ 0000-0003-0941-9070

*** Arş. Gör., Sakarya Universitesi, Eğitim Fakültesi, Yabancı Diller Eğitimi Bölümü, İngilizce Öğretmenliği Programı, Sakarya, Türkiye. E-posta: msavasci@ sakarya.edu.tr, https://orcid.org/ 0000-0002-4906-3630

${ }_{* * * * *}$ Arş. Gör. Sakarya Universitesi, Eğitim Fakültesi, Eğitim Bilimleri Bölümü, Eğitim Yönetimi ve Denetimi Programı, Sakarya, Türkiye. E-posta: gsezen@sakarya.edu.tr, https://orcid.org/ 0000-0002-2179-4466
} 


\section{Introduction}

The incorporation of technology, particularly of information and communication technologies (ICT), has radically changed the educational settings in recent years. For example, virtual learning environments have been created, which resulted in the emergence of electronic and/or online learning (e-learning hereafter). Simply put, e-learning refers to any type of learning delivered online. It can also be defined as "a web-based communication platform that allows learners, without limitations on place and time, to access diverse learning tools, such as discussion boards, assessments, content repositories, and document sharing systems" (Mohammadyari \& Singh, 2015, p. 12). E-learning systems include Web-based learning (WBL), Internet-based training (IBT), and online learning (OL) (Khan, 2000, as cited in Liaw, Huang \& Chen 2007, p. 1067) and annihilate the limitations of time and place because on the contrary to conventional learning which takes place in physical classroom contexts, e-learning systems enable learners to access information wherever and whenever they want, thereby maximizing learning opportunities.

Accordingly, incorporation of e-learning into education has required developing a fundamental understanding of technology and a set of competencies necessary for using technology. E-learners are thus expected to possess digital literacy skills; that is to say, they should have "the ability to understand and use information in multiple formats from a wide range of sources" (Gilster, 1997, p. 1, as cited in Bawden, 2008, p. 4) by using information technologies and the Internet. Given these, digital literacy skills and e-learning might have a reciprocal relationship.

Moreover, learners' attitudes toward online learning environments might have an effect on their behavioral intentions regarding technology acceptance because as indicated in Davis's (1989) Technology Acceptance Model-1 (TAM), attitude has an effect on behavioral intentions. However, as Cüceloğlu (1991) puts forward, attitudinal changes take place in longer periods of time, and they are not only shaped by emotions and thoughts but also by behaviors. Thus, the acceptance and use of technology is also affected by the perceived benefits and perceived ease of use, which in turn affect attitudes. For example, Chaka and Govender (2017) indicated that the factors of the acceptance model are positively correlated with behavioral intention. As also discussed in Venkatesh and Davis's (2000) model of TAM-2 and Venkatesh and Bala's (2008) model of TAM-3, attitude is one of the strong predictors of behavioral intention. Therefore, this study focuses on attitudes toward e-learning by specifically focusing on the educational platform Edmodo.

\section{E-learning}

Today, e-learning systems are increasingly used at all levels of education and have several benefits (e.g., Concannon, Flynn \& Campbell, 2005; Liaw et al., 2007; Zhang \& Nunamaker, 2003) including time and location flexibility, cost and time savings, self-paced learning, collaborative learning environments, better access to the instructors, and unlimited use of learning materials (Zhang \& Nunamaker, 2003). Several studies in the literature revealed these effects of e-learning (e.g., Cakiroglu, 2014; Chou \& Chen, 2016; Fryer, Bovee \& Nakao, 2014; Lee, 2010; Liaw et al., 2007; Ong \& Lai, 2006; Ozkan \& Koseler, 2009; Selim, 2007). However, e-learning satisfaction depends on well-planned interaction mechanisms since interaction is important for both instructors and students. And in order to facilitate supportive and corrective feedback, instructors must design highly interactive settings (Cakiroglu, 2014). However, as Cheng and Weng (2017) noted, in order to create highly-interactive environments by increasing teacher-student interaction in the class, "the principal is obliged to work together with teachers and parents to provide the support for digital media technology usage" (p. 10).

In another line of research, researchers have explored instructors and learners' attitudes toward e-learning (e.g., Concannon et al., 2005; Liaw et al., 2007), gender differences in relation to e-learning (e.g., Ong \& Lai, 2006), and potential effects of previous experience (e.g., Concannon et al., 2005; Selim, 2007) on attitudes towards e-learning. As Selim (2007) notes, "Student prior IT experience such as having a computer at home and attitude towards e-learning is critical to e-learning success" ( $p$. 399). Accordingly, Liaw et al. (2007) suggest that "...user attitudes toward e-learning could be studied from various perspectives, such as affective, cognitive, behavioral, and social components." (p. 1078). 


\section{Digital Literacy}

Digital literacy refers to "the multiplicity of literacies associated with the use of digital technologies" (p. 1066), and it requires possessing the skills necessary for using technology in teaching-learning processes, and reaching, producing, and sharing information (Hamutoğlu, Güngören-Canan, Uyanık-Kaya, \& Erdoğan-Gür, 2017; Ng, 2012).

Digital literacy has attracted widespread attention in the field (e.g., Burnet \& Merchant, 2014; Martinovic \& Zhang, 2012; Ng, 2012). Nevertheless, studies in the literature have mostly focused on scale development (Hamutoğlu et al., 2017; Ng, 2012; Ustundag, Gunes \& Bahcivan, 2017), being digitally literate (Ustundag et al., 2017) or on emphasizing the importance of being digitally literate. In the literature, the empirical correlational experimental studies are quite limited. That is, although elearning platforms have increasingly been integrated into our lives and despite the reality of our students who were born into digital technologies, no studies have investigated the relationship between digital literacy skills and attitudes toward e-learning.

\section{Significance of the Study and Research Questions}

Students of the new millennium typify "the first generations to grow up with" digital technology (Prensky, 2001, p. 2) and today's students are regarded as "digital natives" (Prensky, 2001, p. 2), which implies that they were born into digital technology and have spent their entire lives with it. Therefore, teaching them by using traditional methods and tools might pose problems in the learning/teaching process. Since they are digital natives and therefore digitally literate, so should their teachers be. Professional development of teachers in ICT, therefore, takes a more important stance from this perspective. Thus, teacher training programs should be closely interested in providing digital technologies and incorporating them into the curriculum at universities, especially in the departments in which prospective teachers are studying.

In light of this background, this study aims to achieve a better understanding of the effects of a five-week e-learning course on prospective teachers' digital literacy skills and their attitudes toward elearning. To put it differently, the present study aims to find out the effects of an e-learning platform (i.e., Edmodo). Even though there are a number of studies subjecting e-learning and digital literacy skills separately, to the best of our knowledge, no studies have investigated the potential relationship between attitudes toward e-learning and digital literacy skills yet. Hence, this study is considered to fill the gap in the literature by providing empirical data with respect to this potential relationship. Furthermore, experimental studies investigating prospective teachers' attitudes toward e-learning are quite limited despite the fact that the importance of attitudes in learning and teaching processes is frequently emphasized (Gagne \& Briggs, 1979). However, it is considered important that prospective teachers be digitally literate. Therefore, exploring prospective teachers' attitudes and knowing the factors that might have an effect on their digital literacy skills has crucial importance.

To this end, this study sought to find an answer to the following questions:

1) What is the effect of an e-learning platform (i.e., Edmodo) on prospective teachers'

a. attitudes towards e-learning prior to and after the treatment?

b. digital literacy skills prior to and after the treatment?

2) Do prospective teachers'

a. attitudes toward e-learning vary according to gender prior to and after the treatment?

b. digital literacy skills vary according to gender prior to and after the treatment?

3) Do prospective teachers'

a. attitudes toward e-learning vary according to prior e-learning experience prior to and after the treatment?

b. digital literacy skills vary according to prior e-learning experience prior to and after the treatment?

4) Is there a relationship between prospective teachers' e-learning attitudes and digital literacy skills?

5) What are the predictors of digital literacy? 


\section{Method}

The study is an example of a quasi-experimental quantitative research design based on a single group pre-and post-test model (see Table 1). Thus, pre and posttests were conducted to investigate the differences in participants' digital literacy skills and their attitudes toward e-learning before and after experimenting with the use of an e-learning system. In this study, Edmodo was used as our e-learning system.

\section{Table 1}

The Pre-Experimental Single Group Pre-Test and Post-Test Design

\begin{tabular}{llll}
\hline Group & Pre-test & Process & Post-test \\
\hline $\mathrm{G}$ & $\mathrm{T}_{1}$ & $\mathrm{X}$ & $\mathrm{T}_{2}$ \\
\hline
\end{tabular}

\section{Participants}

47 undergraduate senior students ( 25 female, 22 male) enrolled in the Department of Computer Education and Instructional Technology (CEIT) at the Faculty of Education at a state university in Turkey in 2016-2017 spring term participated in this study.

At the time the study was conducted, the participants were taking a compulsory course entitled "Internet-based Education", offered as a departmental elective course for senior students. The class met once a week for three hours per week. Regarding their previous e-learning experience, whereas the majority had $(n=34,72.3 \%)$ previous e-learning experience, the remaining $(n=13,27.7 \%)$ did not.

\section{Data Collection Tools}

The data for the study came from two data collection tools: an "Attitude towards E-learning Scale" (Haznedar \& Baran, 2012), and a "Digital Literacy Scale" (Ng, 2012).

The Attitudes towards E-Learning Scale (Haznedar \& Baran, 2012), which was used to measure general attitudes towards e-learning, includes a total of 20 items. The highest score which can be received from the scale is 100. Factor analysis of the Likert scale, which ranged from 1 "Strongly Disagree" to 5 "Strongly Agree", showed that the 20-item e-learning attitude scale can be used both with single factor and two factors. The single factor of the general attitude towards e-learning scale explained $45.12 \%$ of the total variance. The two factor-scale explained $52.23 \%$ of the total variance. Cronbach's Alpha coefficient is .93 for two factor scale. In this study, the scale was used with two factors called tendency towards e-learning and avoidance from e-learning. In the scale, only the 10 items in the sub-dimension avoidance were reverse.

The Digital Literacy Scale $(\mathrm{Ng}, 2012)$ includes 17 items and comprises four sub-dimensions: attitude $(n=7)$, technical $(n=6)$, cognitive $(n=2)$, and social $(n=2)$. The scale is a five-point Likert scale, ranging from 1 "Strongly Disagree" to 5 "Strongly Agree", and does not include any reverse items. The highest score which can be received from the digital literacy scale is 85 . The validity and reliability study was conducted by Hamutoğlu et al. (2017) showed that the factor structure of the original scale was confirmed in the Turkish context. Moreover, Cronbach Alpha was used as an index of reliability, and regarding the overall scale as well as its sub-dimensions -attitude, technical, cognitive, social- the reliability coefficients were as follow: $.93, .88, .89, .70$ and .72 , respectively.

\section{Data Collection Procedure}

This study was conducted as a part of a three-hour course which was offered by one of the researchers, and the study included a five-week treatment. And as an e-learning platform, Edmodo which is a famous online educational technology tool- was used in this study since it helps its members collaborate, share information as well as providing coaching for the students through an online platform.

During the first week of the 14-week semester, the instructor oriented students for the course and administered the pre-tests. In the following week, a session about the Edmodo platform and an 
orientation training which is on the course content were provided for the students. Then, the participants were grouped by their instructors on a voluntary basis; i.e., they were allowed to form their own groups. Each group included approximately four to five students, where they chose their group members on their own will. However, the groups did not change over the treatment, the students worked in the same groups during the treatment period. The weekly plan of the treatment is reported in Table 2 below:

Table 2

Weekly Plan of the Treatment

\begin{tabular}{ll}
\hline Week & Tasks \\
\hline 1 & Orientation \& Administration of pre-tests \\
2 & Edmodo orientation \& How to enroll in a course on Edmodo \\
3 & Individual discussions on Edmodo: E-learning context \\
4 & Group discussions on Edmodo: E-learning applications around the world \\
5 & Group presentations on Edmodo: The importance of e-learning approaches \\
6 & Individual discussions: The use of different technology and new media on the e-learning process \\
7 & Group discussions on Edmodo: The importance of communication and collaboration on e-learning \\
8 & Administration of post-tests \\
\hline
\end{tabular}

Basically, the course content was covered during the conventional class hours which were conducted face-to-face, and the students were assigned to discuss the given activities. Each week, a different task including different activities was assigned to the participants. For example, one of the tasks was "E-learning applications throughout the world". During the week in which this topic was covered, the instructor lectured during the class hours, and after the class, the students made online discussions either with their own group members or individually, based on the planned activities. In essence, the students exchanged information through discussion groups on Edmodo. Afterwards, they prepared reports based on their discussions on Edmodo and uploaded them on ForAllRubrics application. After the completion of activities, the instructor provided weekly feedback on ForAllRubrics application on Edmodo so that the students could see their progress weekly. The course materials were delivered via the Google Drive application, which is embedded in Edmodo. To summarize, Edmodo served as an umbrella platform including ForAllRubrics and Google Drive applications, which were used for creating electronic portfolios (e-portfolios), and delivering and storing course materials, respectively. At the end of the five-week treatment, the posttests were administered.

\section{Data Analysis}

The data were first inspected for any missing values and normality. To meet the assumptions for parametric tests, first of all, multi collinearity and singularity values between the dependent variables were checked, followed by checking the VIF and tolerance values. Secondly, Cook's distance and Leverage values were computed to meet the normality assumptions.

Afterwards, the data were analyzed using descriptive statistics, independent samples t-test, Pearson product-moment correlation, and simple regression analysis.

\section{Findings}

Means, standard deviations, Skewness and Kurtosis values in relation to the Attitude towards Elearning Scale and the Digital Literacy Scale are reported in Table 3. 
Table 3

Descriptive Statistics of the Scales

\begin{tabular}{llllllll}
\hline & $\boldsymbol{N}$ & Min & Max & $\boldsymbol{M}$ & $\boldsymbol{S D}$ & Skewness & Kurtosis \\
\hline E-learning T(pre) & 47 & 56.00 & 74.00 & 64.47 & 3.65 & .24 & .11 \\
E-learning T(post) & 47 & 57.00 & 87.00 & 67.36 & 6.03 & 1.13 & 1.54 \\
TEND (pre) & 47 & 29.00 & 49.00 & 37.51 & 4.95 & .65 & .07 \\
TEND (post) & 47 & 28.00 & 50.00 & 39.55 & 4.91 & .01 & .87 \\
AVOID (pre) & 47 & 16.00 & 36.00 & 26.96 & 4.69 & -.37 & -.32 \\
AVOID (post) & 47 & 16.00 & 44.00 & 27.81 & 5.66 & .53 & .57 \\
Digital Literacy T (pre) & 47 & 56.00 & 85.00 & 71.94 & 7.17 & -.05 & -.58 \\
Digital Literacy T (post) & 47 & 56.00 & 85.00 & 71.64 & 7.72 & .35 & -.74 \\
ATT (pre) & 47 & 22.00 & 35.00 & 30.19 & 3.47 & -.16 & -.80 \\
ATT (post) & 47 & 23.00 & 35.00 & 30.00 & 3.32 & .22 & -.91 \\
TECH (pre) & 47 & 18.00 & 30.00 & 25.04 & 2.59 & -.17 & .20 \\
TECH (post) & 47 & 19.00 & 30.00 & 25.11 & 3.16 & .28 & -.99 \\
COGN (pre) & 47 & 5.00 & 10.00 & 8.23 & 1.22 & -.25 & .09 \\
COGN (post) & 47 & 5.00 & 10.00 & 8.36 & 1.20 & -.28 & .21 \\
SOC-EM (pre) & 47 & 6.00 & 10.00 & 8.47 & 1.10 & -.12 & -.51 \\
SOC-EM (post) & 47 & 4.00 & 10.00 & 8.17 & 1.48 & -.56 & .12 \\
\hline
\end{tabular}

Digital Literacy T- Digital Literacy Total, ATT- Attitude, TECH- Technical, COGN-Cognitive, SOC-EM-

Social-Emotional, E-Learning T- E-learning Total, TEND- Tendency, AVOID- Avoidance

As reported in Table 3, Skewness and Kurtosis values indicate that the data for scales and their sub-dimensions are distributed normally given the Skewness and Kurtosis values ranging between +2.5 and -2.5 (Mertler \& Vannatta, 2005). In other words, Skewness and Kurtosis coefficients for factor scores indicate no deviation from the normal distribution. Mahalanobis Distance value is also inspected considering the independent variables in the dataset $(p<.01)$ (Büyüköztürk, 2005, p. 99). Furthermore, multi collinearity and singularity values are at the moderate level (Akbulut, 2010; Büyüköztürk, 2005; Field, 2005; Pallant, 2005). Additionally, VIF values are smaller than 10 (pre $=2.047$; post $=1.14$ ) and tolerance values are higher than zero (pre $=.489$; post $=.874$ ). Finally, Cook's distance is smaller than 1 and Leverage values are smaller than 0.02 , which suggest that these values meet the normality assumptions. Thus, in accordance with these results, parametric tests were used to analyze the data.

Table 3 also reports the pre and post-test scores for each scale and sub-dimension. When the preand post-test scores are compared, it is seen that the treatment slightly increased the participants' attitudes toward e-learning. On the other hand, it did not have an effect on their digital literacy skills.

In Table 4, the Skewness and Kurtosis values are reported, which show that the data are normality regarding gender. Table 4 also presents the results of pre-test independent sample t-tests in terms of gender which were run to explore the e-learning attitudes and digital literacy skills of the participants prior to the treatment.

\section{Table 4}

The Results of Pre-Test Independent Sample t-Test in Terms of Gender

\begin{tabular}{lllllccccc}
\hline Scale & Gender & $\boldsymbol{n}$ & $\boldsymbol{M}$ & $\boldsymbol{S D}$ & Skewness & Kurtosis & df & t & p \\
\hline \multirow{2}{*}{ E-learning T } & Female & 22 & 63.82 & 3.33 & -.369 & .119 & \multirow{2}{*}{4} & -1.150 & .26 \\
& Male & 25 & 65.04 & 3.88 & .489 & -.276 & & & \\
Digital Literacy & Female & 22 & 74.27 & 6.68 & -.241 & -.977 & 45 & 2.18 & $.03 *$ \\
T & Male & 25 & 69.88 & 7.08 & .167 & .060 & & & \\
\hline
\end{tabular}

*p<.05

Digital Literacy T-Digital Literacy Total, E-Learning T- E-learning Total 
The results showed there were significant differences in digital literacy $\left(\mathrm{t}_{(45)}=2.18, \mathrm{p}<.05\right)$ between males and females. When the arithmetic means were analyzed, it was seen that the female participants $(M=74.27)$ had higher scores than the males $(M=69.88)$ regarding their digital literacy skills. However, no significant difference was found in their attitudes toward e-learning.

Table 5 presents the Skewness and Kurtosis values according to prior e-learning experience, which show that the data are normally distributed. Table 5 also presents the results of pretest independent sample t-test in terms of prior e-learning experience, which was run to explore the elearning attitudes and digital literacy skills of the participants prior to the treatment.

\section{Table 5}

The results of pre-test independent sample t-test in terms of prior e-learning experience variable

\begin{tabular}{lllllccccc}
\hline Scale & $\begin{array}{l}\text { Prior } \\
\text { experience }\end{array}$ & $\boldsymbol{n}$ & $\boldsymbol{M}$ & $\boldsymbol{S D}$ & Skewness & Kurtosis & df & t & $\mathbf{p}$ \\
\hline E-learning & Yes & 34 & 64.41 & 3.92 & .253 & .088 & & - & .87 \\
T & No & 13 & 64.62 & 2.93 & .378 & -.822 & 45 & .179 & .87 \\
Digital & Yes & 34 & 72.47 & 6.92 & -.060 & -.638 & & & \\
Literacy T & No & 13 & 70.54 & 7.89 & .078 & -.220 & & .823 & .42 \\
\hline
\end{tabular}

$* \mathrm{p}<.05, * * \mathrm{p}<.01$

Digital Literacy T-Digital Literacy Total, E-Learning T- E-learning Total

As indicated in Table 5, findings did not elicit a significant difference their attitudes toward elearning or their digital literacy skills with respect to their prior experience.

In Table 6, the Skewness and Kurtosis values are given, showing that the data are distributed normally in terms of gender. Furthermore, Table 6 also presents the results of post-test independent sample t-test in terms of gender, which was run to explore the e-learning attitudes and digital literacy skills of the participants after the treatment.

\section{Table 6}

The results of post-test independent sample t-test in terms of gender

\begin{tabular}{llllllllll}
\hline Scale & Gender & $\boldsymbol{n}$ & $\boldsymbol{M}$ & $\boldsymbol{S D}$ & Skewness & Kurtosis & df & t & p \\
\hline E-learning & Female & 22 & 67.72 & 6.51 & 1.280 & 2.433 & & \multirow{2}{*}{.386} & .70 \\
T & Male & 25 & 67.04 & 5.70 & .969 & .374 & 45 & & \\
Digital & Female & 22 & 71.81 & 6.76 & .613 & -.964 & \multirow{2}{*}{.148} & .88 \\
Literacy T & Male & 25 & 71.48 & 8.62 & .272 & -.794 & & .148 \\
\hline
\end{tabular}

\footnotetext{
$* \mathrm{p}<.05, * * \mathrm{p}<.01$

Digital Literacy T-Digital Literacy Total, E-Learning T- E-learning Total
}

The results showed that there was no significant difference in any dimensions in terms of gender (p> .05). In this context, it can be stated that the views on e-learning and digital literacy of the female and male participants did not differ from each other.

As indicated in Table 7 , the data are distributed normally according to prior e-learning experience. Table 7 also presents the results of post-test independent sample t-test in terms of prior elearning experience, which was run to explore the e-learning attitudes and digital literacy skills of the participants after the treatment. 


\section{Table 7}

The results of post-test independent sample t-test in terms of prior e-learning experience variable

\begin{tabular}{lllllccccc}
\hline Scale & $\begin{array}{l}\text { Prior } \\
\text { experience }\end{array}$ & $\boldsymbol{n}$ & $\boldsymbol{M}$ & $\boldsymbol{S D}$ & Skewness & Kurtosis & df & $\mathbf{t}$ & $\mathbf{p}$ \\
\hline \multirow{2}{*}{ E-learning T } & Yes & 34 & 67.09 & 6.24 & 1.286 & 2.189 & \multirow{2}{*}{45} & -.498 & .62 \\
& No & 13 & 68.08 & 5.63 & .805 & .176 & & & \\
\multirow{2}{*}{ Digital Literacy T } & Yes & 34 & 71.38 & 7.23 & .572 & -.535 & \multirow{2}{*}{4} & -.364 & .72 \\
& No & 13 & 72.30 & 9.18 & -.037 & -1.000 & & & \\
\hline
\end{tabular}

*p<.05, **p<.01

Digital Literacy T-Digital Literacy Total, E-Learning T- E-learning Total

It can be stated that the views on e-learning and digital literacy held by the participants who had prior e-learning experience and the ones who did not have such experience did not differ from each other. Table 8 presents the results of the paired sample t-test, which was run to explore the e-learning attitudes and digital literacy skills of the participants prior to and after the treatment.

\section{Table 8}

The results of paired sample t-test in terms of pre-and-post tests

\begin{tabular}{|c|c|c|c|c|c|c|c|}
\hline Scale & Tests & $N$ & $M$ & $S D$ & $\mathrm{df}$ & $\mathrm{t}$ & $\mathrm{p}$ \\
\hline \multirow[t]{2}{*}{ E-Learning $\mathrm{T}$} & Pre & 47 & 64.47 & 3.64 & 46 & -3.192 & $.003 * *$ \\
\hline & Post & 47 & 67.36 & 6.03 & & & \\
\hline \multirow[t]{2}{*}{ TEND } & Pre & 47 & 37.51 & 4.95 & 46 & -2.366 & $.022 *$ \\
\hline & Post & 47 & 39.55 & 4.91 & & & \\
\hline \multirow[t]{2}{*}{ AVOID } & Pre & 47 & 26.96 & 4.69 & 46 & -.922 & .361 \\
\hline & Post & 47 & 27.81 & 5.66 & & & \\
\hline \multirow[t]{2}{*}{ Digital Literacy T } & Pre & 47 & 71.94 & 7.17 & 46 & .249 & .804 \\
\hline & Post & 47 & 71.64 & 7.72 & & & \\
\hline \multirow[t]{2}{*}{ ATT } & Pre & 47 & 30.19 & 3.47 & 46 & .379 & .707 \\
\hline & Post & 47 & 30.00 & 3.32 & & & \\
\hline \multirow[t]{2}{*}{ TECH } & Pre & 47 & 25.04 & 2.59 & 46 & -.130 & .897 \\
\hline & Post & 47 & 25.11 & 3.16 & & & \\
\hline \multirow[t]{2}{*}{ COGN } & Pre & 47 & 8.23 & 1.22 & 46 & -.544 & .589 \\
\hline & Post & 47 & 8.36 & 1.20 & & & \\
\hline \multirow[t]{2}{*}{ SOC-EM } & Pre & 47 & 8.47 & 1.10 & 46 & 1.298 & .201 \\
\hline & Post & 47 & 8.17 & 1.48 & & & \\
\hline \multirow[b]{2}{*}{ E-Learning $\mathrm{T}$} & Pre & 47 & 64.47 & 3.64 & & & \\
\hline & Post & 47 & 67.36 & 6.03 & 46 & -3.192 & $.003 * *$ \\
\hline \multirow{2}{*}{ Digital Literacy T } & Pre & 47 & 71.94 & 7.17 & \multirow{2}{*}{46} & \multirow{2}{*}{.249} & \multirow{2}{*}{.804} \\
\hline & Post & 47 & 71.64 & 7.72 & & & \\
\hline
\end{tabular}

$* \mathrm{p}<.05, * * \mathrm{p}<.01$

Digital Literacy T- Digital Literacy Total, ATT- Attitude, TECH- Technical, COGN-Cognitive, SOC-EM-

Social-Emotional, E-Learning T- E-learning Total, TEND- Tendency, AVOID- Avoidance 
Table 8 also reports the results of the paired sample t-tests which were run to explore the e-learning attitudes and digital literacy skills of the participants prior to and after the treatment. The results showed that there was a significant difference between the pre-test and the post test results in terms of e-learning attitudes $(\mathrm{t}(46)=-3.192, \mathrm{p}<0.01)$. When the arithmetic means were analyzed, it was seen that the post-test results $(M$ $=67.36)$ were higher than the pre- test results $(M=64.47)$. Similarly, there was a significant difference in the sub-dimension tendency (of the e-learning attitude scale) $(\mathrm{t}(46)=-2.366, \mathrm{p}<0.05)$. When the arithmetic means were analyzed, it was seen that the post-test results $(M=39.55)$ were higher than the pre-test results $(M=37.51)$. However, no significant difference was found in the other sub-dimensions of e-learning attitudes, digital literacy skills and its sub-dimensions.

Table 9 presents the results of the Pearson Correlation test to see the relationship between elearning attitudes and digital literacy skills of the participants in the pre-test.

\section{Table 9}

Pearson Correlation Matrix on the Relationship between E-learning Attitude and Digital Literacy in terms of pre-test results

\begin{tabular}{|c|c|c|c|c|c|c|c|c|}
\hline & $\begin{array}{l}\text { Digital } \\
\text { Literacy T }\end{array}$ & ATT & TECH & COGN & SOC-EM & $\begin{array}{c}\text { E-learning } \\
\mathrm{T}\end{array}$ & TEND & AVOID \\
\hline $\begin{array}{l}\text { Digital } \\
\text { Literacy T }\end{array}$ & 1 & $.922 * *$ & $.874 * *$ & $.827 * *$ & $.632 * *$ & -.031 & .245 & -.283 \\
\hline ATT & - & 1 & $.674 * *$ & $.682 * *$ & $.511 * *$ & -.091 & .188 & -.269 \\
\hline TECH & - & - & 1 & $.713 * *$ & $.428 * *$ & .131 & $.319 *$ & -.235 \\
\hline COGN & - & - & - & 1 & $.451 * *$ & -.123 & .228 & $-.336^{*}$ \\
\hline SOC-EM & - & - & - & - & 1 & -.088 & .003 & -.072 \\
\hline E-learning $\mathrm{T}$ & - & - & - & - & - & 1 & $.438 * *$ & $.315^{*}$ \\
\hline TEND & - & - & - & - & - & - & 1 & $-.715^{* *}$ \\
\hline AVOID & - & - & - & - & - & - & - & 1 \\
\hline
\end{tabular}

$* \mathrm{p}<.05, * * \mathrm{p}<.01$

Digital Literacy T- Digital Literacy Total, ATT- Attitude, TECH- Technical, COGN-Cognitive, SOC-EMSocial-Emotional, E-Learning T- E-learning Total, TEND- Tendency, AVOID- Avoidance

The results showed that there was no relationship between e-learning attitudes and digital literacy $(\mathrm{r}=-.031 ; \mathrm{p}>0.05)$, and its sub-dimensions $(\mathrm{r}=-.091, \mathrm{r}=.131, \mathrm{r}=-.123, \mathrm{r}=-.088 ; \mathrm{p}>.05)$ before the treatment. When considered in terms of tendency sub-dimension, a positive moderate significant relationship was found only between tendency and technical sub-dimension $(r=.319 ; \mathrm{p}<$ $.05)$ while there was not any significant difference between tendency sub-dimension and digital literacy $(\mathrm{r}=.245 ; \mathrm{p}>.05)$, and attitude, cognitive, social-emotional sub-dimensions $(\mathrm{r}=.188, \mathrm{r}=$ $.228, \mathrm{r}=.003 ; \mathrm{p}>.05)$ before the treatment. On the other hand, a negative moderate significant relationship was found only between avoidance sub-dimension and cognitive sub-dimension $(\mathrm{r}=-$ $.336 ; \mathrm{p}<.05$ ) while there was not any significant difference between avoidance sub-dimension and digital literacy $(r=-.283 ; \mathrm{p}>.05)$, and attitude, technical, social-emotional sub-dimensions $(\mathrm{r}=-.269$, $\mathrm{r}=-.235, \mathrm{r}=-.072 ; \mathrm{p}>.05)$ before the treatment.

Table 10 presents the results of the Pearson Correlation test showing the relationship between elearning attitudes and digital literacy skills of the participants in the post-test.

Results indicated no relationship between e-learning attitudes and digital literacy $(r=.241 ; \mathrm{p}>$ $.05)$, and its sub-dimensions $(\mathrm{r}=.262, \mathrm{r}=.176, \mathrm{r}=.110, \mathrm{r}=.205 ; \mathrm{p}>.05)$ after the treatment. Similarly, no relationship was found between avoidance sub-dimension and digital literacy $(r=-.221$; $\mathrm{p}>.05)$, and its sub-dimensions $(\mathrm{r}=-.239, \mathrm{r}=-.239, \mathrm{r}=-.165, \mathrm{r}=.025 ; \mathrm{p}>.05)$ after the treatment. When considered in terms of tendency sub-dimension, some positive moderate significant relationships were found between tendency and relatively digital literacy $(\mathrm{r}=.551 ; \mathrm{p}<.01)$, attitude $(\mathrm{r}$ $=.597 ; \mathrm{p}<.01)$, technical $(\mathrm{r}=.491 ; \mathrm{p}<.01)$, cognitive $(\mathrm{r}=.325 ; \mathrm{p}<.05)$ while there was no relationship between tendency and social-emotional $(\mathrm{r}=.223, \mathrm{p}>.05)$ after the treatment. 


\section{Table 10}

Pearson Correlation Matrix on the Relationship between E-learning Attitude and Digital Literacy in terms of post-test results

\begin{tabular}{|c|c|c|c|c|c|c|c|c|}
\hline & $\begin{array}{c}\text { Digital } \\
\text { Literacy } \mathrm{T}\end{array}$ & ATT & TECH & COGN & SOC-EM & $\begin{array}{c}\text { E-learning } \\
\mathrm{T}\end{array}$ & TEND & AVOID \\
\hline $\begin{array}{l}\text { Digital } \\
\text { Literacy T }\end{array}$ & 1 & $.870 * *$ & $.905 * *$ & $.792 * *$ & $.693 * *$ & .241 & $.551 * *$ & -.221 \\
\hline ATT & - & 1 & $.660 * *$ & $.511^{* *}$ & $.474 * *$ & .262 & $.597 * *$ & -.239 \\
\hline TECH & - & - & 1 & $.744 * *$ & $.503 * *$ & .176 & $.491 * *$ & -.239 \\
\hline COGN & - & - & - & 1 & $.586^{* *}$ & .110 & $.325^{*}$ & -.165 \\
\hline SOC-EM & - & - & - & - & 1 & .205 & .223 & .025 \\
\hline E-learning $T$ & - & - & - & - & - & 1 & $.481 * *$ & $.649 * *$ \\
\hline TEND & - & - & - & - & - & - & 1 & $-.355^{*}$ \\
\hline AVOID & - & - & - & - & - & - & - & 1 \\
\hline
\end{tabular}

$* \mathrm{p}<.05, * * \mathrm{p}<.01$

Digital Literacy T- Digital Literacy Total, ATT- Attitude, TECH- Technical, COGN-Cognitive, SOC-EM-

Social-Emotional, E-Learning T- E-learning Total, TEND- Tendency, AVOID-Avoidance

The relationships between tendency and digital literacy, and its sub-dimensions except socialemotional sub-dimension were analyzed by simple regression analysis technique, which are presented in Table 11.

Table 11

Linear Regression using Tendency to Predict Cognitive, Technical, and Attitude sub-dimension, and Digital Literacy

\begin{tabular}{|c|c|c|c|c|c|c|c|c|}
\hline $\begin{array}{l}\text { Variabl } \\
\text { es }\end{array}$ & $\begin{array}{l}\text { COGN } \\
\text { (Constant) }\end{array}$ & TEND & $\begin{array}{l}\text { TECH } \\
\text { (Constant) }\end{array}$ & $\begin{array}{l}\text { TEND } \\
\text { (Total) }\end{array}$ & $\begin{array}{l}\text { ATT } \\
\text { (Constant) }\end{array}$ & TEND & $\begin{array}{l}\text { Digital } \\
\text { Literacy T } \\
\text { (Constant) }\end{array}$ & TEND \\
\hline$M$ & 8.36 & 39.55 & 25.11 & 39.55 & 30.00 & 39.55 & 71.64 & 39.55 \\
\hline$S D$ & 1.20 & 4.91 & 3.16 & 4.91 & 3.32 & 4.91 & 7.72 & 4.91 \\
\hline$N$ & 47 & 47 & 47 & 47 & 47 & 47 & 47 & 47 \\
\hline B & 5.20 & .080 & 12.62 & .316 & 14.07 & .403 & 37.40 & .866 \\
\hline SE & 1.38 & .03 & 3.33 & .083 & 3.22 & .081 & 7.80 & .196 \\
\hline Beta & & .325 & & .491 & & .597 & & .551 \\
\hline $\mathrm{t}$ & 3.774 & 2.308 & 3.794 & 3.781 & 4.369 & 4.986 & 4.797 & 4.424 \\
\hline $\mathrm{p}$ & .000 & .026 & .000 & .000 & .000 & .000 & .000 & .000 \\
\hline Paired $\mathrm{r}$ & & .325 & & .491 & & .597 & & .551 \\
\hline Partial r & & .325 & & .491 & & .597 & & .551 \\
\hline & \multicolumn{2}{|c|}{$\begin{array}{l}\mathrm{F}_{(1-46)}=5.325 \\
\mathrm{p}=.026^{*} \\
\mathrm{R}=.325 \\
\mathrm{R}^{2}=.110 \\
\mathrm{n}^{2}=0,12\end{array}$} & \multicolumn{2}{|c|}{$\begin{array}{l}\mathrm{F}_{(1-46)}=14.298 \\
\mathrm{p}=.000^{* *} \\
\mathrm{R}=.491 \\
\mathrm{R}^{2}=.241 \\
\mathrm{n}^{2}=.32\end{array}$} & \multicolumn{2}{|c|}{$\begin{array}{l}\mathrm{F}_{(1-46)}=24.862 \\
\mathrm{p}=.000 * * \\
\mathrm{R}=.597 \\
\mathrm{R}^{2}=.356 \\
\mathrm{n}^{2}=0,55\end{array}$} & \multicolumn{2}{|l|}{$\begin{array}{l}\mathrm{F}_{(1-46)}=19 . \\
\mathrm{p}=.000^{* *} \\
\mathrm{R}=.551 \\
\mathrm{R}^{2}=.303 \\
\mathrm{n}^{2}=0,43\end{array}$} \\
\hline
\end{tabular}

$* \mathrm{p}<.05, * * \mathrm{p}<.01$

Digital Literacy T- Digital Literacy Total, ATT- Attitude, TECH- Technical, COGN-Cognitive, TENDTendency

When the results are examined, it is seen that tendency explains relatively digital literacy $(\mathrm{R}=$ $\left..55, \mathrm{R}^{2}=.30, \mathrm{~F}=19.56, \mathrm{p}<.01\right)$; attitude $\left(\mathrm{R}=.59, \mathrm{R}^{2}=.35, \mathrm{~F}=24.86, \mathrm{p}<.01\right)$; technical $(\mathrm{R}=.49$, $\left.\mathrm{R}^{2}=.24, \mathrm{~F}=14.29, \mathrm{p}<.01\right)$; cognitive $\left(\mathrm{R}=.32, \mathrm{R}^{2}=.11, \mathrm{~F}=5.32, \mathrm{p}<.05\right)$ at a significant level. According to these results, tendency explains relatively $30 \%$ of the variance in digital literacy; $35 \%$ of 
attitude; $24 \%$ of technical and $11 \%$ of cognitive. In this context, it can be stated that tendency is a significant predictor for digital literacy and its sub-dimensions attitude, technical and cognitive literacy.

\section{Discussion and Conclusion and Recommendations}

This study aimed to explore the effect of an e-learning platform on participants' digital literacy skills and their attitudes towards e-learning. For the purposes of the study, one of the prevalent elearning platforms- Edmodo, was incorporated into the course syllabus in this study. The study, where a pre and post-test quasi-experimental design was adopted, was conducted with prospective teachers over a five-week treatment period, and the data were obtained by the "General Attitude Scale towards E-learning" (Haznedar \& Baran, 2012) and the "Digital Literacy Scale" (Ng, 2012). The results overall demonstrated that whereas a significant change was observed in the participants' attitudes toward e-learning, it did not have a significant impact on their digital literacy skills. The results are further discussed more in-depth as follow.

As also indicated in the results, a paired samples t-test comparing the pre- and post-test results indicated that the treatment significantly affected the attitudes of participants towards e-learning platforms. Chaka and Govender (2017) addressed the perception of students toward mobile learning based on an acceptance model and found that the factors of the acceptance model were positively correlated with behavioral intention. However, it is worth to note that attitude is one of the strong predictors of behavioral intention (Venkatesh \& Bala, 2008). Actually, attitude is a string and latent variable which is resistant to changes. In this context, the results of this study illustrate that the treatment was so effective that the attitude towards e-learning platforms showed a difference between pre- and post-tests analysis. Moreover, previous experience with e-learning and gender were other variables which were investigated regarding participants' attitudes toward e-learning. At the beginning of the treatment, previous experience was not correlated with attitudes towards e-learning platforms, which concurs with Concannon et al. (2005)'s study. Concannon et al. (2005) in their study found that previous experience with computers should not be the main concern; rather, students' attitude is a more important factor. In their study, even though nearly $15 \%$ of the participants did not have or had limited prior experience with computers, none of them stated difficulties while using technologies. Therefore, it is noted that participants' attitudes is a strong a predictor on the use of these technologies. On the other hand, gender, similarly, did not have a significant impact on the attitudes of participants toward e-learning in this study.

The paired samples t-tests results also indicated that the treatment did not significantly affect the participants' digital literacy skills because in the treatment, the planned activities were mainly based on peer and collaborative learning rather than on setting the students to work on improving their digital literacy skills. Therefore, the treatment did not aim to change the digital literacy skills of the participants. In addition to this, the findings could be explained considering the participants' exposes to digital technologies such as smartphone, tablet, etc. in their daily lives. That is why we should not expect statistically significant changes, especially after a treatment which only lasted for five weeks. Furthermore, the predictors of digital literacy and its sub-dimensions (attitude, cognitive, technical, and social-emotional) were investigated. Considering the correlational analyses, the results are as follow:

Before the treatment, attitudes toward e-learning did not have any relationship with any of the sub-dimensions of digital literacy - attitude, technical, cognitive, social-emotional. With respect to elearning and its sub-dimensions, avoidance had a negative moderate significant relationship with the cognitive sub-dimension of digital literacy. It was not correlated with the other sub-dimensionsattitude, technical, social-emotional. The sub-dimension tendency had a positive moderate significant relationship with the technical sub-dimension of digital literacy. Yet, it was not correlated with the other sub-dimensions -attitude, cognitive, social-emotional.

After the treatment, the results demonstrated that attitudes toward e-learning were not correlated with any of the sub-dimensions of digital literacy, either. However, some changes were observed regarding the sub-dimensions of e-learning; i.e., regarding tendency and avoidance. Avoidance was not correlated with any of the sub-dimensions of digital literacy whereas tendency was positively 
correlated with digital literacy $(\mathrm{r}=.551 ; \mathrm{p}<.01)$, and with the following sub-dimensions: attitude $(\mathrm{r}=$ $.597 ; \mathrm{p}<.01)$, technical $(\mathrm{r}=.491 ; \mathrm{p}<.01)$, and cognitive $(\mathrm{r}=.325 ; \mathrm{p}<.05)$. The treatment did not affect the sub-dimension social-emotional.

In terms of participants' attitudes toward e-learning, there was no relationship with digital literacy or with its any sub-dimensions. Digital literacy did not correlate with attitude because we consider that the activities assigned for participants did not aim to/ did not make the participants engage in digital literacy skills. In order to develop digital literacy skills, participants should define and analyze the data which they obtain from the digital medium. In this study, we do not exactly know how the participants obtained the data within the scope of the activities presented with Edmodo, that is, whether they obtained the information from a digital medium or not. It is probable that the participants might have used published hard-copy sources, or they might have obtained information from their group members by exchanging information or through discussion; there was not a control mechanism for checking this process. Besides, we only used one e-learning platform- Edmodo. In light of these, the result that there is not a correlation between digital literacy skills and their attitudes toward e-learning can be meaningful. Future studies might be conducted over long periods of time or in a different medium with well-designed activities.

Regarding avoidance and sub-dimension of e-learning, -there was a negative moderate significant relationship between avoidance and cognitive sub-dimension before the treatment. However, the treatment helped neutralize this relationship. The participants were expected to avoid the medium since they were not cognitively competent at the beginning of the treatment. Therefore, this finding is meaningful since they are not familiar with the medium or cognitively mature enough. However, after the treatment, the avoidance of the participants disappeared at the post-test, with experience. Even though this relationship was not positively correlated, longer-term studies in which experience is maximized are considered to possibly be more effective in terms of avoidance. To summarize, the result of the treatments neutralized the negative effects on cognitive sub-dimension of digital literacy within the context of avoidance.

The main effects of the treatment can be observed on the regression results which show tendency is a significant predictor for digital literacy and its all sub-dimensions attitude, technical and cognitive literacy except for the social-emotional sub-dimension. Considering the features of tendency, it is meaningful to have a positive relationship with the total score of digital literacy because tendency might change with experience. As participants gain experience with e-learning platforms, their tendency toward e-learning increases as well. According to Cüceloğlu (1991), attitude is long-term, and it is not only shaped by emotions and thoughts, but also by behaviors. Therefore, it can be stated that temporary tendencies that are not observed for a long time are not seen as attitudes (Hamutoğlu, 2013). Considering the relationship between tendency and technical sub-dimensions, they were correlated even before the treatment, and it was maintained after the treatment as well. Considering participants' background (they were senior students enrolled in the Department of Computer Education and Instructional Technology), the results are meaningful. At the beginning of the treatment, tendency and cognitive were not correlated, yet after the treatment a positive moderate significant relationship with cognitive after the treatment, meaning that they became cognitively ready. The tendency, however, was not correlated with the sub-dimension social-emotional. When the items in the sub-dimension social-emotional are examined, it is expected that the activities assigned for a five-week treatment period do not have an effect on the tendency.

All in all, this study investigated the correlation between the digital literacy skills of prospectiveteachers based on e-learning attitudes and its sub-dimensions such as tendency and avoidance through the one of the emerging instructional technology such as using Edmodo, by implementing pedagogical approaches. The results of the present study might be helpful to facilitate better learning, increase motivation, and adopt the 21 st-century skills than the ones that are sought by the traditional classroom environments. However, in this digital era, not only being able to use the technologies but also their potential effects from a pedagogical perspective should be addressed more in depth. In addition to this, future studies may examine in depth based on qualitative research methods for the students' attitudes toward digital technologies. This study was, therefore, an attempt to contribute to the body of research on digital technologies from a pedagogical perspective. 


\section{Implications}

This study revealed that attitude has an important place in the acceptance of technology and predicts the intention toward the use of that technology, and it provides several implications.

Unearthing the factors that might have an effect on teachers' digital literacy has an important place, and teachers should focus on the issues that might affect their attitudes. It is also considered that providing more opportunities for prospective teachers to increase their experience in e-learning platforms might help them enhance their digital literacy skills since these platforms have a significant effect on their attitudes. All in all, it can be implied that tendency through the use of these kinds of elearning platforms help individuals improve their digital literacy skills. It is recommended for future research(er)s that how prospective teachers' opinions about e-learning platforms, and how these platforms affect their learning in-depth.

\section{References}

Akbulut, Y. (2010). Sosyal bilimlerde SPSS uygulamaları (1.Bask1) [SPSS applications in social sciences $\left(1^{\text {st }}\right.$ ed. $\left.)\right]$. İstanbul: İdeal Kültür Publishing.

Bawden, D. (2008). Origins and concepts of digital literacy. Digital Literacies: Concepts, Policies and Practices, 30, 17-32.

Burnet, C., \& Merchant, G. (2014). Points of view: Reconceptualising literacies through an exploration of adult and child interactions in a virtual world. Journal of Research in Reading, 37(1), 36-50. http://dx.doi.org/10.1111/jrir.12006

Büyüköztürk, Ş. (2005). Sosyal bilimler için veri analizi el kitabı (Gözden geçirilmiş 5. Bask1) [Data analysis hand book for social sciences (Revised $5^{\text {th }}$ ed.)] Ankara: Pegem Akademi Publishing.

Cakiroglu, U. (2014). Evaluating students' perspectives about virtual classrooms with regard to seven principles of good practice. South African Journal of Education, 34(2), 1-12.

Chaka, G. J., \& Govendar, I. (2017). Students' perceptions and readiness towards mobile learning in colleges of education: A Nigerian perspective. South African Journal of Education, 37(1), 1-12.

Cheng, Y. H., \& Weng, C. W. (2017). Factors influence the digital media teaching of primary school teachers in a flipped class: A Taiwan case study. South African Journal of Education, 37(1), 1-12.

Chou, H. L., \& Chen, C. H. (2016). Beyond identifying privacy issues in e-learning settings: Implications for instructional designers. Computers \& Education, 103, 124-133.

Concannon, F., Flynn, A., \& Campbell, M. (2005). What campus-based students think about the quality and benefits of e-learning. British Journal of Educational Technology, 36(3), 501-512.

Cüceloğlu, D. (1991). İnsan ve davranışl: Psikolojinin temel kavramları [Human and behavior: Basic concepts of psychology]. İstanbul: Remzi Kitapevi Publishing.

Davis, F. D. (1989). Perceived usefulness, perceived ease of use, and user acceptance of information technology. MIS quarterly, 319-340.

Field, A. (2005). Discovering statistics: Using SPSS. London: SAGE Publications Ltd.

Fryer, L. K., Bovee, H. N., \& Nakao, K. (2014). E-learning: Reasons students in language learning courses don't want to. Computers \& Education, 74, 26-36.

Gagne, R. M., \& Briggs, L. J. (1979). Principles of instructional design. New York: Holt, Rinehart and Winston.

Hamutoğlu, N. B. (2013). Karma öğretim öğrencilerinin sosyal ağlardan Facebook’a karşı tutumları (Saü eğitim fakültesi örneği) (Yayınlanmamış yükseklisans tezi) [The attitudes of blended students towards social networks Facebook: SAU college of education sample (Unpublished Master Thesis)], Sakarya University, Sakarya. 
Hamutoğlu, N. B., Güngören-Canan, O., Uyanık-Kaya, G., \& Erdoğan-Gür, D. (2017). Adapting digital literacy scale into Turkish. Ege Journal of Education, 18(1), 408-429.

Haznedar, O., \& Baran, B. (2012). Development of a general attitude scale towards e-learning for faculty of education students. Educational Technology Theory and Practice, 2(2), 42-59.

Lee, M. C. (2010). Explaining and predicting users' continuance intention toward e-learning: An extension of the expectation-confirmation model. Computers \& Education, 54(2), 506-516.

Liaw, S. S., Huang, H. M., \& Chen, G. D. (2007). Surveying instructor and learner attitudes toward elearning. Computers \& Education, 49(4), 1066-1080.

Martinovic, D., \& Zhang, Z. (2012). Situating ICT in the teacher education program: Overcoming challenges, fulfilling expectations. Teaching and Teacher Education, 28(3), 461-469.

Mertler, C. A., \& Vanatta, R. A. (2005). Advanced and multivariate statistical methods (3rd ed.). Glendale, CA: Pyrzcak Publishing.

Mohammadyari, S., \& Singh, H. (2015). Understanding the effect of e-learning on individual performance: The role of digital literacy. Computers \& Education, 82, 11-25.

$\mathrm{Ng}, \mathrm{W}$. (2012). Can we teach digital natives digital literacy? Computers \& Education, 59, 1065-1078.

Ong, C. S., \& Lai, J. Y. (2006). Gender differences in perceptions and relationships among dominants of e-learning acceptance. Computers in Human Behavior, 22(5), 816-829.

Ozkan, S., \& Koseler, R. (2009). Multi-dimensional students' evaluation of e-learning systems in the higher education context: An empirical investigation. Computers \& Education, 53(4), 1285-1296.

Pallant, J. (2005). SPSS survival manual: A step by step guide to data analysis using SPSS for Windows ( $2^{\text {nd }}$ ed.). New York, NY: Open University Press..

Prensky, M. (2001). Digital natives, digital immigrants. On the Horizon, 9(5), 1-6.

Selim, H. M. (2007). Critical success factors for e-learning acceptance: Confirmatory factor models. Computers \& Education, 49(2), 396-413.

Ustundag, M. T., Gunes, E., \& Bahcivan, E. (2017). Turkish Adaptation of digital literacy scale and investigating pre-service science teachers' digital literacy. Journal of Education, 12, 19-29.

Venkatesh, V., \& Bala, H. (2008). Technology Acceptance Model 3 and a research agenda on interventions. Decision Sciences, 39(2), 273-315.

Venkatesh, V., \& Davis, F. D. (2000). A theoretical extension of the technology acceptance model: Four longitudinal field studies. Management science, 46(2), 186-204.

Zhang, D., \& Nunamaker, J. F. (2003). Powering e-learning in the new millennium: an overview of elearning and enabling technology. Information Systems Frontiers, 5(2), 207-218. 